\title{
The influence of nicotine in healing of small bowel anastomoses in rats: angiogenesis and miofibroblasts
}

\section{A influência da nicotina na cicatrização de anastomoses do intestino delgado em ratos: angiogênese e miofibroblastos}

James Skinovsky, TCBC-PR ${ }^{\text {; }}$ Osvaldo Malafaia, ECBC-PR²; Mauricio Chibata ${ }^{1}$; Fernanda Tsumanuma3; Flávio Panegalli Filho ${ }^{3}$; Marcus Vinícius Dantas de Campos Martins, TCBC-RJ"4.

\section{A B S T R A C T}

Objective: to know the effect of nicotine on angiogenesis and myofibroblast formation in anastomoses of the small bowel of rats. Methods: we randomly divided 60 Wistar rats into the groups Nicotine $(\mathrm{N})$ and control $(\mathrm{C})$, according to the proposed treatment. Each group was subdivided into three subgroups according to the time interval used for the evaluation $(7,14$ or 28 days). The $\mathrm{N}$ group with 30 animals received nicotine subcutaneously at a dose of $2 \mathrm{mg} / \mathrm{kg}$ body weight, diluted in $0.3 \mathrm{ml}$ of $0.9 \%$ saline, twice daily for 28 days prior to the operation, and for more 7, 14 or 28 days, depending on the subgroup. The $C$ group (also 30 animals) received only saline on the same conditions and time intervals. After 28 days we carried out an end-to-end anastomosis $10 \mathrm{~cm}$ distal to the duodenojejunal flexure in each rat. After 7, 14 or 28 days after surgery, we euthanized ten animals of each group, sent specimens of the anastomosis areas, $1 \mathrm{~cm}$ proximal to $1 \mathrm{~cm}$ distal, to counting of blood vessels and myofibroblasts through immunohistochemical staining by the application of monoclonal anti-factor VIII antibodies and anti-smooth muscle alpha-actin. Results: the administration of nicotine led to the decrease in the number of blood vessels measured on the 28th postoperative day and the number of myofibroblasts measured on the seventh day following completion of the anastomoses. Conclusion: administration of nicotine was deleterious on angiogenesis and myofibroblast formation in rats' small intestine anastomoses.

Keywords: Wound Healing. Nicotine. Intestine, Small. Anastomosis, Surgical. Rats.

\section{INTRODUCTION}

W ith the growing concern and the global debate on the harmful effects of tobacco on the human body, much attention has been directed to the adverse consequences of smoking. The direct and indirect costs related to diseases linked to smoking consume considerable resources for health in our country. Neoplasms, cardiovascular and respiratory diseases associated with smoking are well documented. However, less attention has been paid to surgical complications related to smoking ${ }^{1-4}$.

Although tobacco products are consumed for hundreds of years, only in the twentieth century there was a sharp increase in consumption, the cigarette being the most important form of use. Its toxic smoke has more than 5,000 elements, of which nicotine is the primary vasoactive component, considered to cause the smoker's addic- tion, as it strengthens and enhances the desire to smoke ${ }^{3,5,6}$.

The so-called granulation tissue, essential for a healthy scar development, comes at the beginning of the second stage of healing, called proliferative, being mainly composed of newly formed blood vessels (angiogenesis) and modified fibroblasts, called myofibroblasts4. While angiogenesis provides the blood supply suitable for the high level of metabolic activity that the healing process requires, myofibroblasts, through their contractile force, approach the damaged tissue edges ${ }^{7}$.

In 1977, Mosely and Finseth ${ }^{8}$ drew attention in a pioneering way to the undesirable effects of nicotine on tissue healing. Since then, several clinical and experimental studies have tried to explain these effects, demonstrating that this substance causes deficiencies in several factors involved in the healing process, in areas as diverse as Plastic Surgery and Orthopedics ${ }^{9}$.

1 - Curso de Medicina da Universidade Positivo, Curitiba - PR, Brasil; 2 - Departamento de Cirurgia da Universidade Federal do Paraná, Curitiba - PR, Brasil; 3 - Hospital Universitário da Cruz Vermelha - Universidade Positivo, Curitiba - PR, Brasil; 4 - Curso de Medicina da Universidade Estácio de Sá, Rio de Janeiro - RJ, Brasil. 


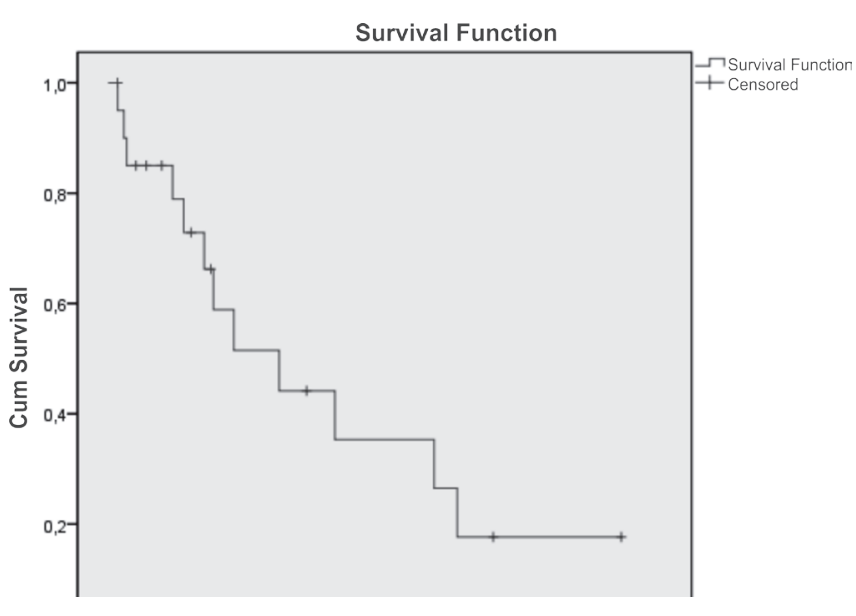

Figure 1 - Nicotine Subcutaneous administration.

Very little is known about the influence of nicotine on healing of the digestive tract, as well as the possible mechanisms involved10-13.

The aim of this study is to analyze the effects of nicotine on the healing process of anastomoses of the small intestine of rats as for the number of blood vessels and myofibroblasts present in the scar tissue.

\section{METHODS}

We performed the experimental procedures in the Surgical Research Center of the Post-Graduation Program in Surgery of the Universidade Federal of Paraná, and the immunohistochemical study at the Pathology Department, Hospital de Clínicas, Universidade Federal do Paraná, and at the Instituto de Pesquisas Médicas (Ipem) of the Hospital Universitário Evangélico de Curitiba, being duly previously reviewed and approved by ethics in research review committees of the aforementioned institutions.

This study used 60 male Wistar rats aged 160-200 days (average 180) and weighting between 270 and 290g, coming from the Instituto de Tecnologia do Paraná (TECPAR), being held in 12-hour day / night cycles and constant room temperature of $240 \mathrm{C}$. The animals fed on chow proper for the species and had free access to water throughout the experiment.

We randomly divided the rats into two groups: Group N, with 30 animals submitted to the application of nicotine; and Group C, also with 30 rats, which served as a control. Each group was divided into three subgroups of ten rats each. They were thus named N7, N14, N28, C7, C14 and C28, according to the postoperative evaluation time.

In group $\mathrm{N}$ nicotine was administered (Nicotine dihydrogen tartrate salt - Sigma, Saint Louis, Missouri, USA) subcutaneously (Figure 1) at the dose of $2 \mathrm{mg}$ per $\mathrm{kg}$ bodyweight twice a day (12/12 hours) diluted in $0.3 \mathrm{ml} 0.9 \%$ saline and adjusted to $\mathrm{pH} 7.4$, for an initial period of 28 days prior to the surgical procedure. In group C we proceeded in an identical manner, though substituting the nicotine for $0.9 \%$ saline solution. The rats were weighed weekly, and the dose of nicotine adjusted when necessary. This dosage was established after calculation so that the amount of nicotine were equivalent to two cigarette cards per day in an adult human.

On the 28th day of application we withdrew feeding for 12 hours prior to the operation, maintaining free access to water. The surgical procedure took place the next day.

The rats were subjected to inhalation anesthesia with halothane in a fume cupboard. We aseptically held a $4 \mathrm{~cm}$ long laparotomy and performed an intestinal anastomosis $10 \mathrm{~cm}$ distal to the duodenojejunal flexure, performing a cross section of the isolated bowel loop and an end-to-end anastomosis, with 6-0 polypropylene suture in a single plane with separated full-thickness stitches, in a total of eight stitches (Figure 2). The wall of the abdomen was closed in two planes, with a continuous running suture with 3-0 multifilament polyglactin. The animals received free access to water immediately, and to food, 12 hours after the procedure.

The administration of nicotine or saline solution remained even on the day of operation and for more 7, 14 or 28 days according the animal's subgroup, and on the same already reported conditions, when we held a new inhalational anesthesia and harvested the anastomosed segments considering $1 \mathrm{~cm}$ proximal to $1 \mathrm{~cm}$ distal to the anastomotic line, preserving the specimen in buffered formalin.

For immunohistochemical staining we applied anti-factor VIII monoclonal antibodies (polyclonal, Code 0082 - DakoCytomation - Carpin- 


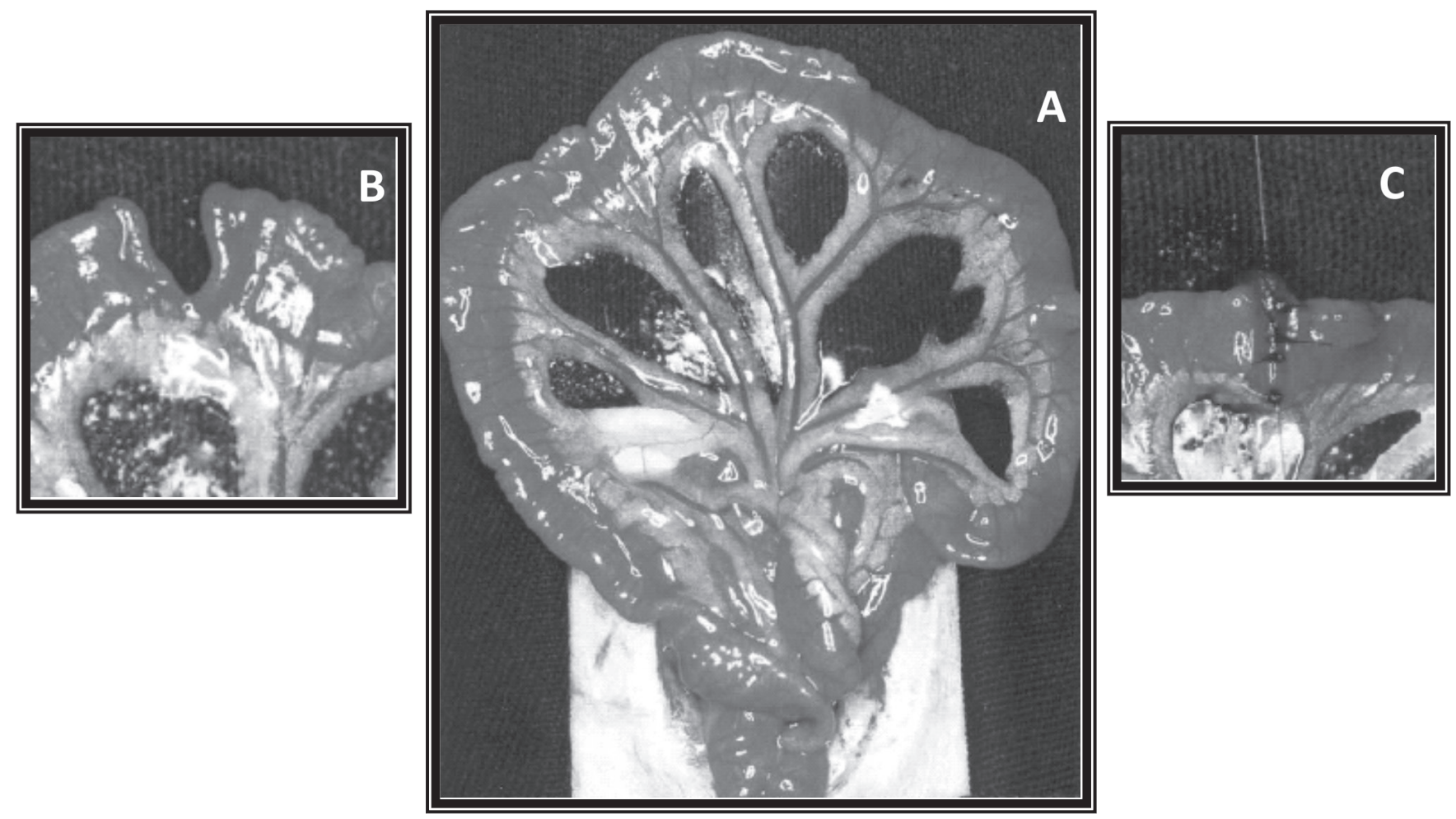

Figure 2. Anastomosis construction in the small intestine. A) intact intestine; B) section of the intestinal loop; C) anastomosis.

teria, USA) and anti-smooth muscle alpha-actin (Monoclonal Antibody, M0851 Code - DakoCytomation - Carpinteria, USA). We identified the myofibroblasts positivity in the areas of brownish pigmentation and we used positive and negative controls.

We identified the number of blood vessels by counting the circular structures positively stained by the anti-factor VIII antibody, which reveals the endothelial cells of the vessels' tunica intima. Counting was done in the area of the anastomosis, in a extension $10 \mathrm{~mm}$ proximal and $10 \mathrm{~mm}$ distal to it (total $20 \mathrm{~mm}$ included with the anastomosis) with $10 \mathrm{x}$ magnification.

As for the quantification of myofibroblasts, we counted the perianastomotic cells positively stained for anti-smooth muscle alpha-actin antibody in a high-power field (40X objective). The scanned images were captured and analyzed by Image Pro Plus (Media Cybernetics, California, USA), through the "Measures" tool.

For each of the quantitative variables we adopted the Mann-Whitney nonparametric test, at a $5 \%$ significance level.

\section{RESULTS}

The evaluation of the number of blood vessels in the area of the anastomosis in the various phases of the postoperative period can be seen in Table 1. The administration of nicotine lead to a decrease in the number of blood vessels measured on the 28th postoperative day and in the number of myofibroblasts measured on the seventh day after the anastomoses.

The microscopic appearance of blood vessels with positivity for anti-factor VIII in shown in Figure 3.

The quantification of myofibroblasts in the various postoperative stages is shown in Table 2. An image of a myofibroblast stained by anti-alpha-actin antibody is seen in Figure 4.

\section{DISCUSSION}

In this experiment we observed that the use of nicotine led to a statistically significant decrease in the number of blood vessels on the 28th postoperative day and in the number of myofibroblasts on 


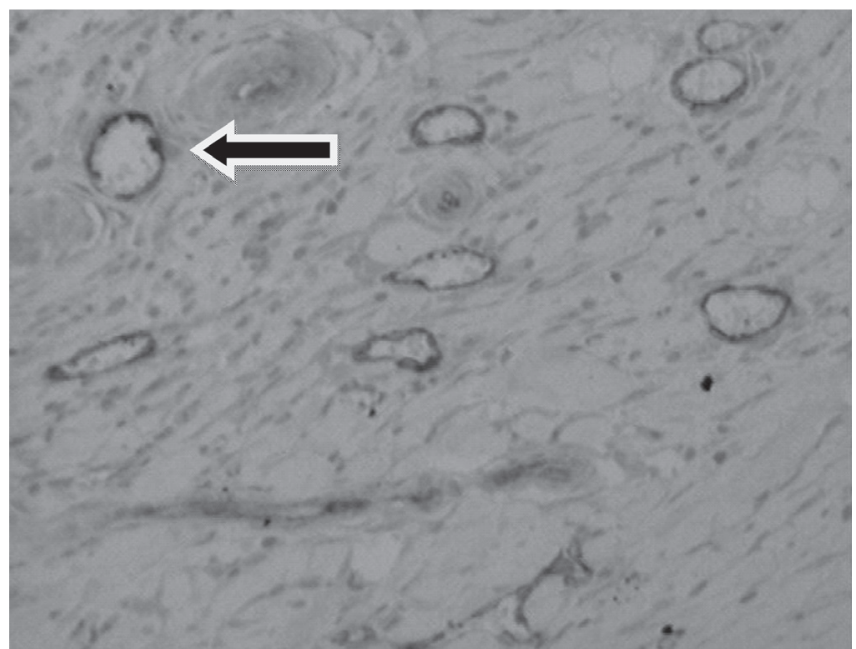

Figure 3. Blood vessels with intima stained in brown, showing positivity for anti-factor VIII (original magnification 100X).

the seventh day following completion of the anastomoses. Similarly, many previous studies determined that this drug acts negatively on the healing process in various tissues, leading to tissue vasoconstriction, decreased proliferation of lymphocytes, fibroblasts and collagen, among others14-21. The lymphocytes are an important source of angiogenesis-inducing cytokine production. Therefore, reduction of lymphocytes by nicotine18 can lead to decreased formation of new blood vessels in the scar tissue, as observed in this study. It is important to remember that the oxygen carried through the new vessels is a key factor in the synthesis of collagen, mainly responsible for the resistance in the scar tissue. Thus, decreased angiogenesis, with consequent deficit of oxygen in the scar tissue, may be one explanation for the decrease in collagen production and rupture strength in the region of intestinal anastomoses identified by previous studies3,7.

Table 1. Number of blood vessels in the 7th, 14th and 28th postoperative days

\begin{tabular}{lccc}
\hline $\begin{array}{c}\text { Number of } \\
\text { vessels }\end{array}$ & Group & Mean \pm SD & p value \\
\hline 7 days & Control & $170.89 \pm 57.74$ & 1.0000 \\
& Nicotine & $159.33 \pm 72.46$ & \\
\hline 14 days & Control & $177.56 \pm 126.66$ & 0.2973 \\
& Nicotine & $107.89 \pm 59.24$ & \\
\hline 28 days & Control & $118.67 \pm 71.48$ & 0.0027 \\
& Nicotine & $62.11 \pm 57.26$ & \\
\hline
\end{tabular}

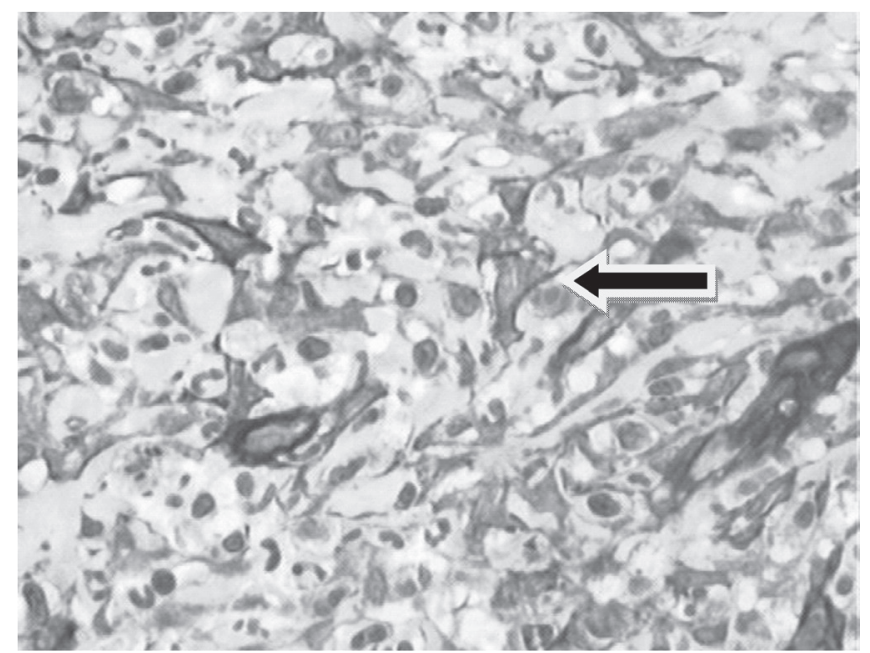

Figure 4. Myofibroblasts stained in brown (anti-smooth muscle alpha-actin antibody), showing polygonal shape with cytoplasmic projections and vesicular nuclei (400X original magnification).

Therefore, nicotine may exert inhibiting effect on angiogenesis through several mechanisms: a- inhibition of angiogenic factors, either by direct negative action in their release mechanism or by deleterious effects on the cells that produce them, such as lymphocytes and fibroblasts5,13,18,19; b- direct deleterious effect on the endothelial cells5,11,19.

Nicotine also reduces the formation of fibroblasts in the healing process of intestinal anastomoses, which explains the deficit of collagen, mainly responsible for local rupture strength5.13, since these cells are the main source of production of that protein. As fibroblasts are the precursor cells of myofibroblasts, whose main function is to promote the approximation of the healing wound edges, the very formation of the latter would also be compromised.

Nicotine may therefore have a negative effect on the proliferation of myofibroblasts through different mechanisms: a- inhibition of the fibroblast precursors of

Table 2. Quantification of myofibroblasts number on the 7th, 14th and 28th postoperative days

\begin{tabular}{lccc}
\hline $\begin{array}{c}\text { Number of } \\
\text { myofibroblasts }\end{array}$ & Group & Mean \pm SD & p value \\
\hline 7 days & Control & $19.67 \pm 6.16$ & 0.0206 \\
& Nicotine & $13.63 \pm 2.62$ & \\
\hline 14 days & Control & $16.75 \pm 6.16$ & 0.6730 \\
& Nicotine & $17.89 \pm 5.99$ & \\
\hline 28 days & Control & $16.67 \pm 6.06$ & 0.0027 \\
& Nicotine & $14.63 \pm 3.89$ & \\
\hline
\end{tabular}


myofibroblasts, either by direct action or by decreasing the oxygen level at the injury site, hampering multiplication and the functioning of these cells13; b- inhibition of cells producing fibroblast-proliferation stimulating cytokines, such as macrophages and lymphocytes15.

Many can be the mechanisms by which nicotine can exert harmful effects on the normal healing process. These should be clarified by further studies, as there are not enough previous works in the literature that have done this analysis for comparison.

In conclusion, according the data presented in this study, administration of nicotine was deleterious to angiogenesis and to myofibroblast formation in anastomoses of the small intestine of rats.

\section{R E S U M O}

Objetivo: conhecer o efeito da nicotina sobre a angiogênese e formação de miofibroblastos em anastomoses do intestino delgado de ratos. Métodos: sessenta ratos Wistar foram divididos de maneira aleatória em grupos Nicotina( $N$ ) e Controle (C), conforme o tratamento proposto. Cada grupo foi subdividido em três subgrupos, de acordo com o intervalo de tempo utilizado para a avaliação (7, 14 ou 28 dias). O grupo N, com 30 animais, recebeu nicotina por via subcutânea, na dose de $2 \mathrm{mg} / \mathrm{Kg}$ de peso, diluída em 0,3m/ de solução salina a 0,9\%, em duas aplicações diárias, durante 28 dias prévios à operação e por mais 7, 14 ou 28 dias, conforme o subgrupo. O grupo C (igualmente com 30 animais) recebeu somente a solução salina nas mesmas condições e intervalos de tempo. Após 28 dias efetuou-se, em cada rato, anastomose término-terminal a 10cm da flexura duodenojejunal. Após 7, 14 ou 28 dias da cirurgia, os dez animais de cada subgrupo foram eutanasiados, sendo que as áreas anastomosadas, $1 \mathrm{~cm}$ proximal a $1 \mathrm{~cm}$ distal, foram encaminhadas para contagem de vasos sanguíneos e miofibroblastos, através de coloração imuno-histoquímica por aplicação dos anticorpos monoclonais antifator VIII e anti-alfa-actina muscular lisa. Resultados: a administração de nicotina levou à diminuição do número de vasos sanguíneos aferidos no 28o dia pós-operatório e do número de miofibroblastos aferidos no sétimo dia após a realização das anastomoses. Conclusão: a administração de nicotina foi deletéria sobre a angiogênese e formação de miofibroblastos em anastomoses do intestino delgado de ratos.

Descritores: Cicatrização. Nicotina. Intestino Delgado. Anastomose Cirúrgica. Ratos.

\section{REFERENCES}

1. Bozarth MA, Pudiak CM, Kuolee R. Effect of chronic nicotine on brain stimulation reward. I. Effect of daily injections. Behav Brain Res. 1998;96(1-2):185-8.

2. Coelho ICMM. Estudo comparativo das forças e tensão entre as cicatrizes das laparotomias paramedianas e das laparotomias transversas em ratos jovens (Rattus Norvegicus Albonus) [dissertação]. Curitiba: Universidade Federal do Paraná, Programa de PósGraduação em Clínica Cirúrgica; 1999.

3. Frick WG, Seals RR Jr. Smoking and wound healing: a review. Tex Dent J. 1994;111(6):21-3.

4. Silva VLC. Tabagismo: um problema de saúde pública no Brasil. JBM. 1990;59(1):14-24.

5. Giannopoulou C, Geinoz A, Cimasoni G. Effects of nicotine on periodontal ligament fibroblasts in vitro. J Clin Periodontol. 1999;26(1):49-55.

6. Fletcher HG. The history of nicotine. J Chem Educ. 1941;18(7):303-8.

7. Witte MB, Barbul A. General principles of wound healing. Surg Clin North Am. 1997;77(3):509-28.

8. Mosely LH, Finseth F. Cigarette smoking: impairment of digital blood flow and wound healing in the hand. Hand. 1977;9(2):97-101.

9. Forrest $R$, Pang $Y$, Lindsay K. Detrimental effect of nicotine on skin flap viability and blood flow in random skin flap operation on rats and pigs. Surg Forum. 1985;36:611-3.

10. Sørensen LT, Toft BG, Rygaard J, Ladelund S, Paddon $M$, James $T$, et al. Effect of smoking, smoking cessation, and nicotine patch on wound dimension, vitamin C, and systemic markers of collagen metabolism. Surgery.2010;148(5):982-90.

11. Medeiros AC, Carvalho MGF, Medeiros MHO, Uchôa RAC. Efeitos da nicotina na cicatrização intestinal em ratos. Rev Col Bras Cir. 1999;26(6):375-8.

12. Adamsons RJ, Musco F, Enquist IF. The relationschip of collagen content to wound strength in normal and scorbutic animals. Surg Gynecol Obstet. 1964;119:323-9.

13. Skinovsky J, Malafaia O, Matias JEF, Ioshi SO, Chibayta M, Campos $A C L$, et al. Nicotina interfere na cicatrização de anastomoses do intestino delgado em ratos. ABCD, arq bras cir dig. 2001;14(4):151-4.

14. Orgill $D$, Demling R. Current concepts and approaches to wound healing. Crit Care Med. 1988;16(9):899-908. 
15. Xanthoulea S, Deliaert A, Romano A, Rensen SS, Buurman WA, van der Hulst RR. Nicotine effect on inflammatory and growth factor responses in murine cutaneous wound healing. Int Immunopharmacol. 2013;17(4):1155-64.

16. Watts DT. The effect of nicotine and smoking on the secretion of epinephrine. Ann N Y Acad Sci. 1960;90(3):74-80.

17. Hesp FL, Hendriks T, Lubbers EJ, deBoer HH. Wound healing in the intestinal wall. A comparison between ileal and colonic anastomoses. Dis Colon Rectum. 1984;27(2):99-104.

18. Neher GH. Nicotine-induced depression of lymphocyte growth. Toxic Appl Pharmacol. 1974;27(2):253-8.

19. Tipton DA, Dabbous MK. Effects of nicotine on proliferation and extracellular matrix production of human gingival fibroblasts in vitro. J Periodontol.
1995;66(12):1056-64.

20. Benowitz N. Clinical pharmacology of nicotine. Ann Rev Med. 1986;37:21-33.

21. Fawcett $A$, Shembekar $M$, Church JS, Vashiht $R$, Springall RG, Nott DM. Smoking, hypertension, and colonic anastomotic healing; a combined clinical and histopathological study. Gut. 1996;38(5):714-8.

Received in: 23/11/2015

Accepted for publication: 13/03/2016

Conflict of interest: none.

Source of funding: none.

Mailing address:

James Skinovsky

Email:skinovsky@gmail.com 